\title{
Link between East Asian summer monsoon and sedimentation in river-mouth sandbars since the early Holocene preserved in the Yangtze River subaqueous delta front
}

\author{
Gang Xu ${ }^{\mathrm{a}, \mathrm{b}}$, Jian Liu ${ }^{\mathrm{a}, \mathrm{b} *}$, Marcello Gugliotta ${ }^{\mathrm{c}}$, Yoshiki Saito ${ }^{\mathrm{c}, \mathrm{d}}$, Lilei Chen ${ }^{\mathrm{a}}$, Xin Zhang ${ }^{\mathrm{a}}$, Gang $\mathrm{Hu}^{\mathrm{a}}$ \\ ${ }^{a}$ Qingdao Institute of Marine Geology, Qingdao 266071, China \\ b Laboratory for Marine Geology, Qingdao National Laboratory for Marine Science and Technology, Qingdao 266061, China \\ ${ }^{c}$ Estuary Research Center, Shimane University, 1060 Nishikawatsu-cho, Matsue 690-8504, Japan \\ ${ }^{\mathrm{d}}$ Geological Survey of Japan, AIST, Central 7, Higashi 1-1-1, Tsukuba, Ibaraki 305-8567, Japan \\ *Corresponding author e-mail address: liujian0550@vip.sina.com (J. Liu).
}

(Received September 20, 2019; ACCEPTED December 30, 2019)

\begin{abstract}
This paper presents geochemical and grain-size records since the early Holocene in core ECS0702 with a fine chronology frame obtained from the Yangtze River subaqueous delta front. Since 9500 cal yr BP, the proxy records of chemical weathering from the Yangtze River basin generally exhibit a Holocene optimum in the early Holocene, a weak East Asian summer monsoon (EASM) period during the middle Holocene, and a relatively strong EASM period in the late Holocene. The $~ 8.2$ and $\sim 4.4$ cal ka BP cooling events are recorded in core ECS0702. The flooding events reconstructed by the grain-size parameters since the early Holocene suggest that the floods mainly occurred during strong EASM periods and the Yangtze River mouth sandbar caused by the floods mainly formed in the early and late Holocene. The Yangtze River-mouth sandbars since the early Holocene shifted from north to south, affected by tidal currents and the Coriolis force, and more importantly, controlled by the EASM. Our results are of great significance for enriching both the record of Holocene climate change in the Yangtze River basin and knowledge about the formation and evolution progress of the deltas located in monsoon regions.
\end{abstract}

Keywords: East Asian summer monsoon; Chemical weathering index; Sensitive grain-size population; River-mouth sandbar; Holocene; Yangtze River subaqueous delta front

\section{INTRODUCTION}

The geologic record shows that large, abrupt, and widespread climate changes occurred repeatedly and on various time scales throughout Earth's history (Gupta et al., 2003). In particular, climate changes that occurred during the Holocene are considered of great importance, as they are crucial for predicting future climatic, natural, and environmental changes (An et al., 2000; Umbanhowar et al., 2006), particularly within the context of global warming. Many studies have suggested that the Holocene was characterized by an unstable climate with several significant centennial- and millennial-scale cooling events (Bond et al., 1997; deMenocal et al., 2000; Gupta et al., 2003).

Cite this article: Xu, G., Liu, J., Gugliotta, M., Saito, Y., Chen, L., Zhang, X., Hu, G. 2020. Link between East Asian summer monsoon and sedimentation in river-mouth sandbars since the early Holocene preserved in the Yangtze River subaqueous delta front. Quaternary Research 95, 84-96. https://doi.org/10.1017/qua.2020.1
The East Asian monsoon (EAM) is an integral part of the global climatic system that is formed as a result of thermal differences between the Asian landmass and the Pacific Ocean (Huang et al., 2018). Extreme events associated with the EAM cause floods and droughts that impact some of the most densely populated regions on Earth. In addition, the interactions of the EAM with El Niño-Southern Oscillation (ENSO) and the midlatitude circulation affect climate at the global scale (Wang et al., 2001). Changes of the EAM throughout the Holocene were identified in the EAM region based on multiple proxies from various geological archives, including loess (Porter and An, 2005), ice cores (Thompson et al., 1989), marine and lacustrine sediments (Nan et al., 2014; Huang et al., 2018), peat deposits (Zheng et al., 2014), and stalagmites (Wang et al., 2005; Hu et al., 2008).

Subaqueous delta fronts on continental shelves provide ideal sites for studying climate records on decadal to millennial time scales due to their high sedimentation rates and preservation potential (Zhou et al., 2012). The Yangtze River is one of the world's largest rivers in terms of water discharge 
$\left(900 \mathrm{~km}^{3} / \mathrm{yr}\right)$ and sediment load (500 Mt/yr before decline) (Milliman and Farnsworth, 2011). The system is strongly influenced by the East Asian summer monsoon (EASM), with approximately $70 \%$ of its annual water discharge and $87 \%$ of its sediment load occurring during the flood season from May to October (Hori et al., 2002). Over the last 7000 years, more than half of the Yangtze River-derived sediment has been stored in the deltaic area, whereas the remaining sediment has been transported southward to form a "mud belt" on the inner shelf along the coast of the Zhejiang and Fujian Provinces (Liu et al., 2007, 2010). The sediments deposited at the river mouth have formed a series of sandbars showing typical seaward migration associated with the deltaic progradation (Milliman et al., 1985).

Stratigraphic, morphologic, and sedimentological studies examining the evolution and modern processes of the Yangtze River delta have been carried out since the late 1970s (Delta Research Group, Department of Marine Geology, Tongji University, 1978; Li et al., 1979). The resulting model, which was widely accepted in a number of studies (Chen et al., 1985; Chen and Stanley, 1993a, 1993b; Li et al., 2000a, 2000b, 2002), highlights a step-like seaward migration of the river-mouth sandbars controlled primarily by tidal currents and the Coriolis force (Fig. 1b). According to these previous studies, the development of river-mouth sandbars from Zhenjiang to the present delta-front area is characterized by the following six stages: Hongqiao stage (7.5-6.0 ${ }^{14} \mathrm{C}$ ka BP), Huangqiao stage $\left(6.5-4.0{ }^{14} \mathrm{C}\right.$ ka BP), Jinsha stage $\left(4.5-2.0{ }^{14} \mathrm{C}\right.$ ka BP), Haimen stage $(2.5-1.2$ ${ }^{14} \mathrm{C}$ ka BP), Chongming stage $\left(1.7-0.2{ }^{14} \mathrm{C}\right.$ ka BP), and Changxing stage $\left(0.7{ }^{14} \mathrm{C}\right.$ ka BP to the present) (Fig. 1b). However, the time of formation of these sandbars is still debated and not entirely constrained. In addition, although some researchers consider the effect of the EASM on the evolution of the Yangtze River delta (Wang et al., 2018; Nian et al., 2019), the role of the EASM in the formation of the sandbars has not been taken into account.

This paper aims to fill that gap by examining core ECS0702 using high-resolution ${ }^{14} \mathrm{C}$ dating of representative elements, grain size, and weathering indexes. These data, combined with previous work, constrain the main Holocene climate events and the formation time of Yangtze Rivermouth sandbars. In addition, the evolution model of the Yangtze River delta since the early Holocene was also reviewed based on the relationships between the development of river-mouth sandbars and EASM fluctuation. Our results are of great significance for enriching both the record of Holocene climate change in the Yangtze River basin and knowledge about the formation and evolution progress of the deltas located in monsoon regions.

\section{MATERIALS AND METHODS}

This study is based on a new borehole core (ECS0702) located on the Yangtze River subaqueous delta front, about $90 \mathrm{~km}$ southeast of the present river mouth (latitude $31^{\circ} 0.004^{\prime} \mathrm{N}$, longitude $122^{\circ} 40.011^{\prime} \mathrm{E}$ ) and at $22 \mathrm{~m}$ water depth (Fig. 1b). The 35.6-m-long core was recovered by the rigging method with an average recovery of $90 \%$. In the laboratory, the sediment core was split, described, and sampled. Sampling at 5 to $15 \mathrm{~cm}$ (253 samples) and 100- to $120-\mathrm{cm}$ (24 samples) intervals were carried out for grain-size and geochemical analyses, respectively. Seventeen samples for ${ }^{14} \mathrm{C}$ dating (plant fragments and molluscan shells) were picked out manually. The experimental process of grain-size analysis, geochemical analysis, and ${ }^{14} \mathrm{C}$ dating were described in detail by Liu et al. (2010). In addition, the sediment core description, vertical distribution characteristics of element/ $\mathrm{Al}$ ratios, and the chronology frame were also reported by Liu et al. (2010). However, the chemical weathering indexes and sensitive grain-size populations used in this paper were not reported.

The chemical weathering intensity of the sediments can be deduced by a quantitative estimation of the chemical weathering of silicates, such as the chemical index of alteration (CIA) (Nesbitt and Young, 1982). The CIA is defined as $\mathrm{Al}_{2} \mathrm{O}_{3} /$ $\left(\mathrm{Al}_{2} \mathrm{O}_{3}+\mathrm{CaO} *+\mathrm{Na}_{2} \mathrm{O}+\mathrm{K}_{2} \mathrm{O}\right) \times 100$ (in molar concentrations, and $\mathrm{CaO}^{*}$ is the $\mathrm{CaO}$ concentration in the silicate fraction of the sample). In this study, the method from McLennan (1993) was adopted to correct the $\mathrm{CaO}^{*}$ content with an assumed specific molar ratio of $\mathrm{CaO} / \mathrm{Na}_{2} \mathrm{O}$ in the silicate mineral; when the molar ratio of $\mathrm{CaO} / \mathrm{Na}_{2} \mathrm{O}$ was greater than 1 , $\mathrm{Na}_{2} \mathrm{O}$ content was substituted for $\mathrm{CaO}$ content in the CIA calculation.

\section{RESULTS}

\section{Element concentration and representative element ratios}

The concentrations of major elements analyzed in sediment core ECS0702 are shown in Figure 2. The concentration range was $13.67 \%$ to $17.26 \%$ (with an average of $16.04 \pm$ $1.03 \%$ ) for $\mathrm{Al}_{2} \mathrm{O}_{3}, 2.54 \%$ to $3.10 \%$ (with an average of $2.86 \pm 0.17 \%$ ) for $\mathrm{MgO}, 1.20 \%$ to $1.75 \%$ (with an average of $1.42 \pm 0.13 \%$ ) for $\mathrm{Na}_{2} \mathrm{O}, 2.53 \%$ to $3.32 \%$ (with an average of $3.05 \pm 0.21 \%$ ) for $\mathrm{K}_{2} \mathrm{O}, 0.760 \%$ to $0.863 \%$ (with an average of $0.822 \pm 0.325 \%$ ) for $\mathrm{TiO}_{2}$, and $2.34 \%$ to $4.75 \%$ (with an average of $3.28 \pm 0.80 \%$ ) for $\mathrm{CaO}$, respectively. The values of representative element ratios in the studied sediment core ranged from 4.73 to 5.26 (average $4.95 \pm 0.14$ ) for $\mathrm{Al} /$ $\mathrm{Mg}$, from 1.73 to 2.87 (average $2.43 \pm 0.30$ ) for $\mathrm{K} / \mathrm{Na}$, and from 0.37 to 0.56 (average $0.47 \pm 0.05$ ) for Ti/ $\mathrm{Na}$. The CIA value ranged from 61.02 to 72.56 (average $67.64 \pm 3.28$ ).

\section{Chronological framework}

The chronology of core ECS0702 according to the accelerator mass spectrometry ${ }^{14} \mathrm{C}$ data has been published by Liu et al. (2010).The dating points are plotted against the original depths as shown in Figure 3a. The studied sediment core accumulated since $\sim 9000 \mathrm{cal}$ yr BP. The sedimentation rate ranged from $0.16 \mathrm{~cm} / \mathrm{yr}$ to $4.98 \mathrm{~cm} / \mathrm{yr}$ and showed a marked 


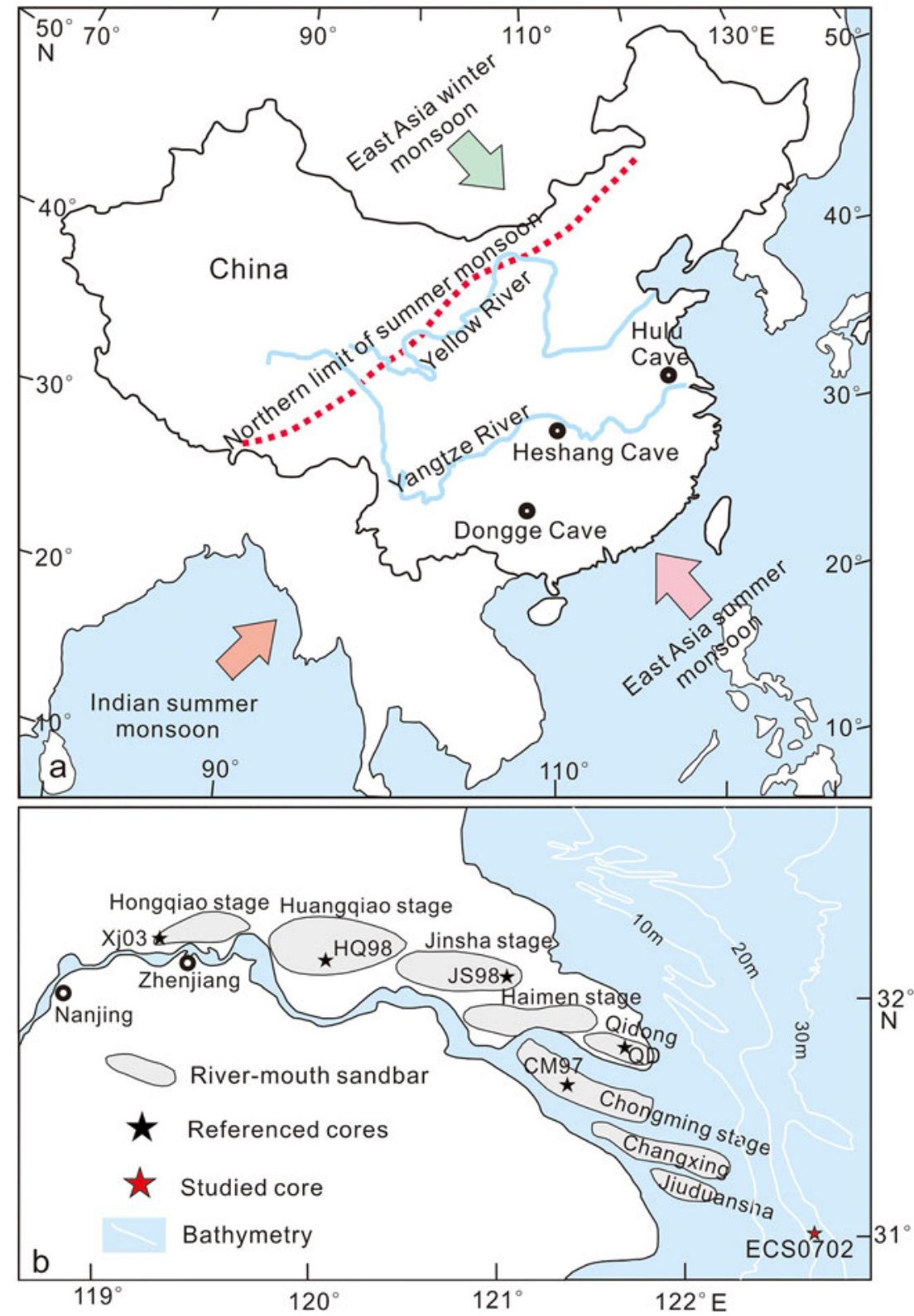

Figure 1. (color online) (a) Map of the current monsoonal climatic system in China with the river course of the Yangtze and Yellow Rivers and locations of the referenced caves Hulu, Heshang, and Dongge. (b) Evolution model for the Yangtze River delta (Delta Research Group, Department of Marine Geology, Tongji University, 1978; Hori et al., 2001) with locations of the studied core ECS0702 and referenced cores Xj03 (Song et al., 2013), HQ98 (Hori et al., 2001; Yi et al., 2003), JS98 (Hori et al., 2001), QD (Liu et al., 1992), and CM97 (Hori et al., 2001 ; Yi et al., 2003).

increase since $\sim 2000$ cal yr BP, especially since $\sim 500$ cal yr BP (Fig. 3b).

We divided the core into two depositional units (DU1 and DU2, in descending order) representing the postglacial sedimentary sequence during the last $\sim 9000 \mathrm{yr}$ based on the results of Liu et al. (2010; Fig. 3c and d). DU2 is a nearshore, subtidal environment upward to the near-shore shelf, with tidal influence in response to the postglacial sea-level rise during 9000-7900 cal yr BP; its main sediment type is coarse-grained sandy silt. DU1 is a tide-affected, nearshore, shallow-sea environment on the delta front of the Yangtze River, when the delta was actively prograding during the last $\sim 7900 \mathrm{cal}$ yr BP; its main sediment type is fine-grained silt. In this region, a high percentage of calcite in detrital mineral assemblages is diagnostic of sediments from the Yellow River (Liu et al., 2010). As shown in Figure 3c, the content of calcite notably increased at $\sim 500$ cal yr BP, indicating that a large amount of Yellow River detritus was introduced. Therefore, the DU1 is also divided into two depositional subunits (DU1-1 and DU1-2) based on the change in sediment sources. The source change at $\sim 500$ cal yr BP poses the question: What is the key factor controlling the deposition of DU1-1 with its much higher depositional rate? 


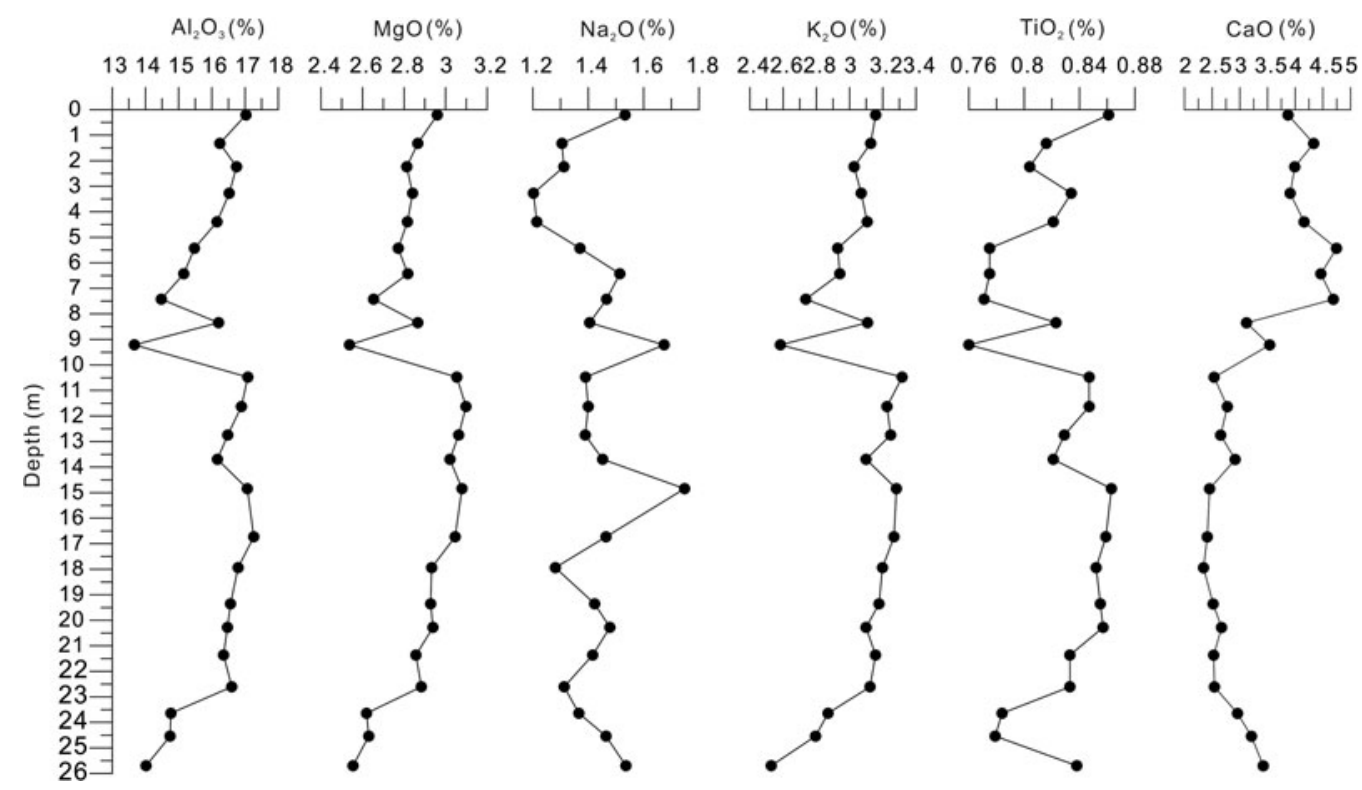

Figure 2. (color online) Vertical variations of major element concentrations in sediment core ECS0702.
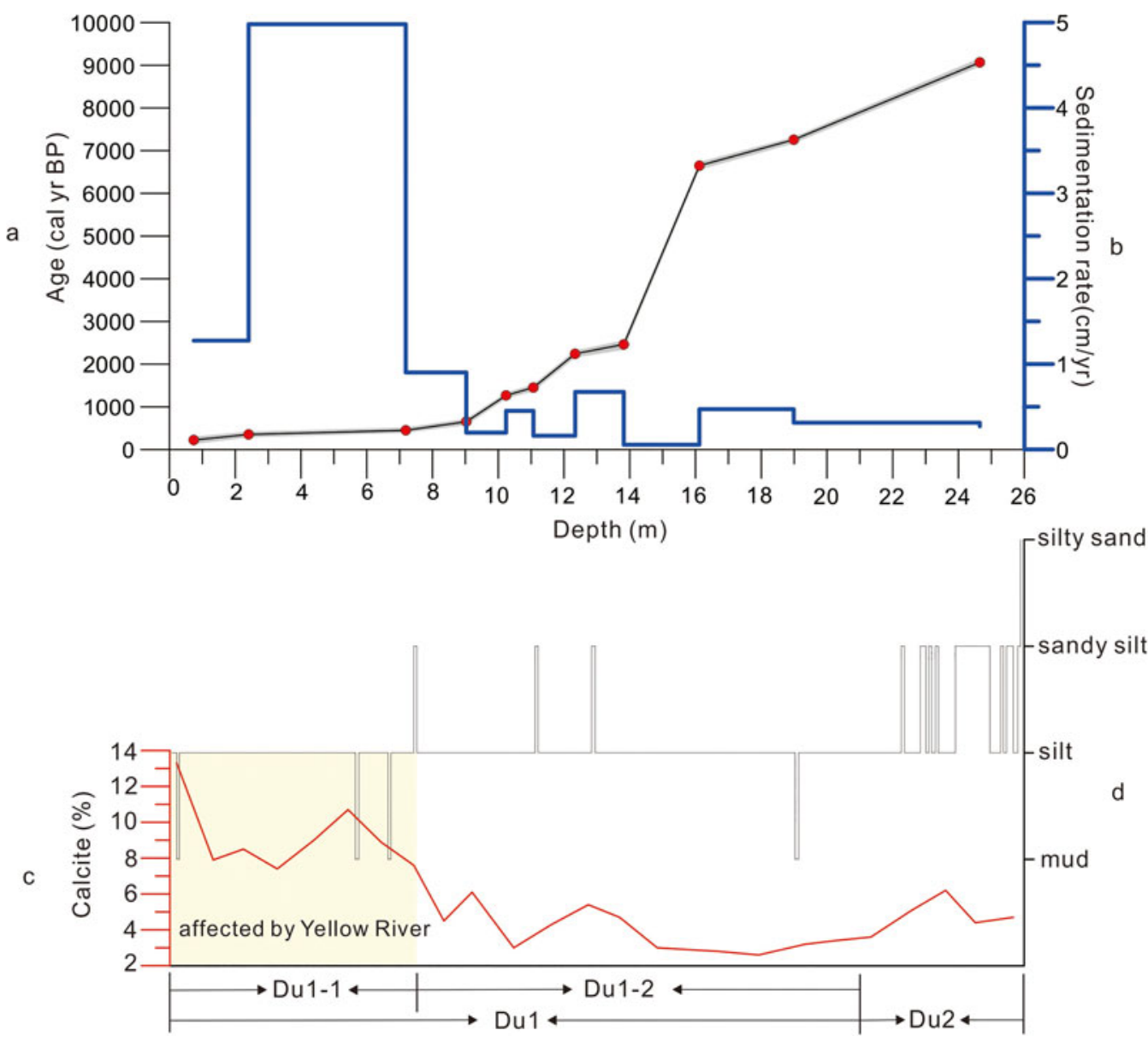

Figure 3. (color online) Chronological framework (a) and linear sedimentation rate (b) of sediment core ECS0702 and vertical distribution of calcite (c) and sediment type based on classification of Folk and Ward (1957) (d). 


\section{Grain-size characteristics}

In this study, the method of plotting grain size versus standard deviation to partition grain-size populations is used to infer the sensitive grain-size populations that are related to paleoclimate evolution. First, the sensitive grain-size populations were extracted based on all sediment samples ( 253 sediment samples) from core ECS0702. As shown in Figure 4, three sensitive grain-size populations were identified in the samples from the studied sediment core: fine sand population (2.5$2.75 \phi)$, medium silt population $(5.25-5.5 \phi)$, and very fine silt population (7.25-7.5 $\phi$ ). As shown in Figure 3c, DU1-1 is notably influenced by detritus from the Yellow River. To eliminate the impact of the Yellow River, the sensitive grainsize populations were extracted based on sediment samples (184 sediment samples) from DU2 and DU1-2, and these results also showed three sensitive grain-size populations: fine sand population $(2.5-2.75 \phi)$, medium silt population $(5.2-5.25 \phi)$, and very fine silt population $(7.2-7.5 \phi)$ (Fig. 4). From the results of these two extractions (Fig. 4), it can be seen that the sensitive grain-size populations of fine sand are identical, which suggests that the fine sand population is the most effective indicator of climatic environment and is less affected by provenance changes.

Size-frequency curves (Fig. 5a-g) show that sediment samples generally have similar characteristics, with a sharp peak in the fine section and a less obviously secondary peak in coarse grains. The cumulative probability curves (Fig. 5a-g) for these samples also show similar characteristics, with higher suspension, secondary saltating components, and a small roll component. However, the sample collected at depth $24.35 \mathrm{~m}$ is obviously different from the overlying samples. It has a sharp peak in the coarse section and a distinct

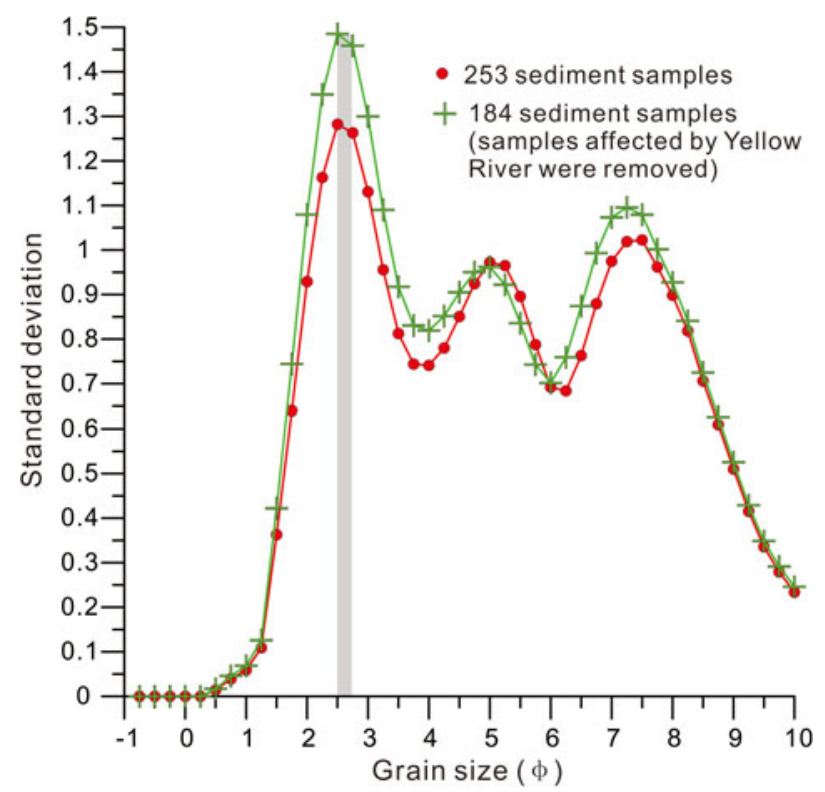

Figure 4. (color online) Grain size vs. standard deviation based all sediment samples (253 sediment samples) and sediment samples only affected by the Yangtze River (184 sediment samples), respectively. secondary peak in the fine section. Its grain size is mainly composed of saltating components (Fig. 5h). The sample collected at a depth $16.05 \mathrm{~m}$ only has a single sharp peak in the fine section, and its grain size is mainly composed of suspended components (Fig. 5i).

\section{DISCUSSION}

\section{Sedimentary record of EASM fluctuation}

Chemical weathering products are the main parts of fluvial sediment load. Therefore, selected special elemental ratios in river-derived sediments, which record information about the variations of elemental concentrations, can be used as chemical weathering indexes to capture climatic changes in a river's catchment (Nesbitt and Young, 1982; Wei et al., 2006). Elemental behaviors are distinctly different during the chemical weathering process (Nath et al., 2000). In general, alkalis and alkaline earth elements are easily removed from primary minerals during chemical weathering. In contrast, some major elements, such as $\mathrm{Al}$ and $\mathrm{Ti}$, tend to be combined in secondary minerals and thus are retained in the chemical weathering products (Nesbitt and Markovics, 1997). In addition, it can be seen that the vertical variations of CIA and element ratios are not controlled by the mean grain size (Fig. 6a-e), sand-sized component, silt-sized component, and clay-sized component (Liu et al., 2010). Therefore, the CIA and $\mathrm{Al} / \mathrm{Mg}, \mathrm{K} / \mathrm{Na}$, and Ti/Na ratios can be used as effective chemical weathering substitution indexes in this study.

The provenance analysis of core ECS0702 suggested that the Yangtze River-derived sediments were the main sources of sediment to the area off the Yangtze estuary until AD 1949, and the source was influenced by Yellow River material only since AD 1950 (Liu et al., 2010). Therefore, the general variation trends of chemical weathering indexes in DU2 and DU1-2 could reflect an overall change of weathering conditions during the Holocene in the Yangtze River basin. The sources of DU1-1 are controlled by both the Yangtze River and Yellow River; therefore, the chemical weathering intensity for DU1-1 is not discussed in this study.

The degree of chemical weathering is primarily controlled by climatic conditions. Warm and humid climatic conditions may favor intense chemical weathering, with humidity playing a particularly significant role (West et al., 2005; Gabet et al., 2006). The Yangtze River basin is currently in a humid subtropical climate that is strongly influenced by the EASM (Zhao et al., 2016), hence proxies for chemical weathering intensity in core ECS0702 could indicate EASM variations. As shown in Figure 6b-e, a striking feature of our analysis is that all chemical weathering proxies, including $\mathrm{CIA}, \mathrm{Al} / \mathrm{Mg}, \mathrm{K} / \mathrm{Na}$, and $\mathrm{Ti} / \mathrm{Na}$ values generally display similar variations throughout the core, with higher values from 9630-9427 to 8504-8326 cal yr BP, 7743-7583 to 7108$6945 \mathrm{cal}$ yr BP, $4427-4226$ to $1392-1240 \mathrm{cal} \mathrm{yr} \mathrm{BP}$, and 815-662 to 648-503 cal yr BP. Except for these periods, the weathering indexes are relatively low. As mentioned earlier, the higher indexes showed that the EASM intensity 

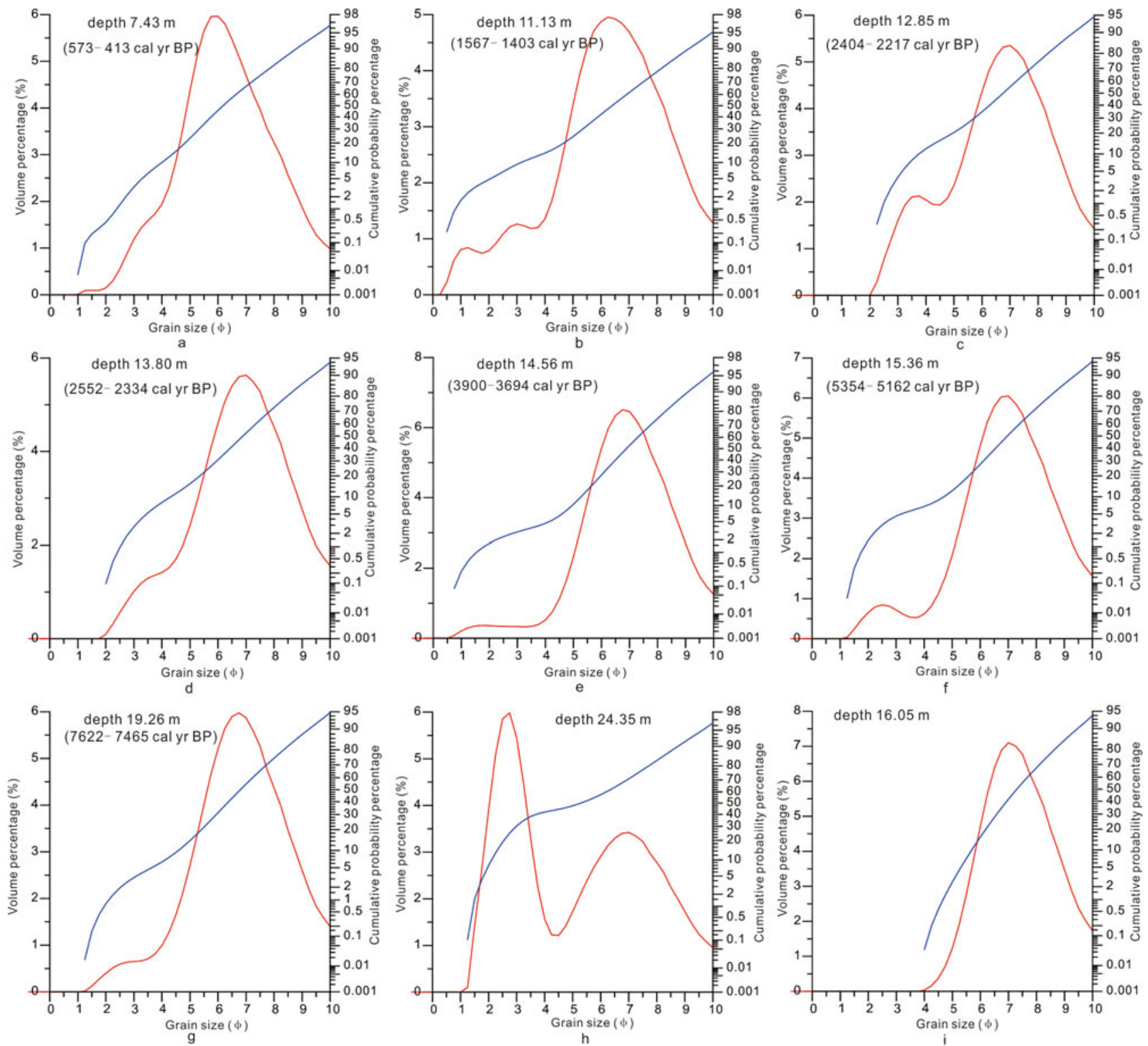

Figure 5. Grain-size distribution curves (red lines) and cumulative probability curves (blue lines) of representative samples in core ECS0702, sample at depth $7.43 \mathrm{~m}$ (a), sample at depth $11.13 \mathrm{~m}$ (b), sample at depth $12.85 \mathrm{~m}$ (c), sample at depth $13.80 \mathrm{~m}(\mathrm{~d})$, sample at depth $14.56 \mathrm{~m}$ (e),

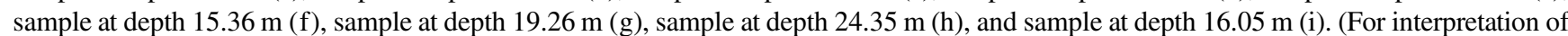
the references to color in this figure legend, the reader is referred to the web version of this article.)

gradually increased in the Holocene, reaching a maximum in the early Holocene ( $7000 \mathrm{cal}$ yr BP) and then becoming relatively weak in the middle Holocene. In the late Holocene ( $\sim 4000$ to $\sim 500$ cal yr BP), the EASM generally strengthened again, but it appears to have been weaker than during the early Holocene.

It is notable that a Holocene optimum in the early Holocene existed in the Yangtze River basin based on the change trend of the EASM proxy indexes in core ECS0702 (Fig. 6). A Holocene optimum in the early Holocene is also evidenced by a high-resolution record of pollen assemblages from Lake Zhuyeze in arid China (Chen et al., 2006; Fig. 6g) and the peat organic carbon isotope record from northeast China (Hong et al., 2003) as well as pollen assemblages (Song et al., 2017) and the oxygen isotope record from Heshang Cave (Hu et al., 2008) in central China. In addition, many reports, including desert (Yang, 2000), lake sediments (Chen et al., 2003), and hopanoid accumulation rates in Dajiuhu peatland (Zhu et al., 2017; Fig. 6h) also indicate the EASM was relatively strong in the early Holocene before 7000 cal yr BP and that a dry climate existed during the middle Holocene in northwest China. Some research suggests that the EASM was much reduced during the middle Holocene in southern China (Zhou et al., 2004). Atmospheric methane concentrations reached a maximum in the early Holocene and subsequently decreased to a minimum during the middle Holocene, also suggesting that the Holocene optimum occurred in the early Holocene (Zheng et al., 2014). It 


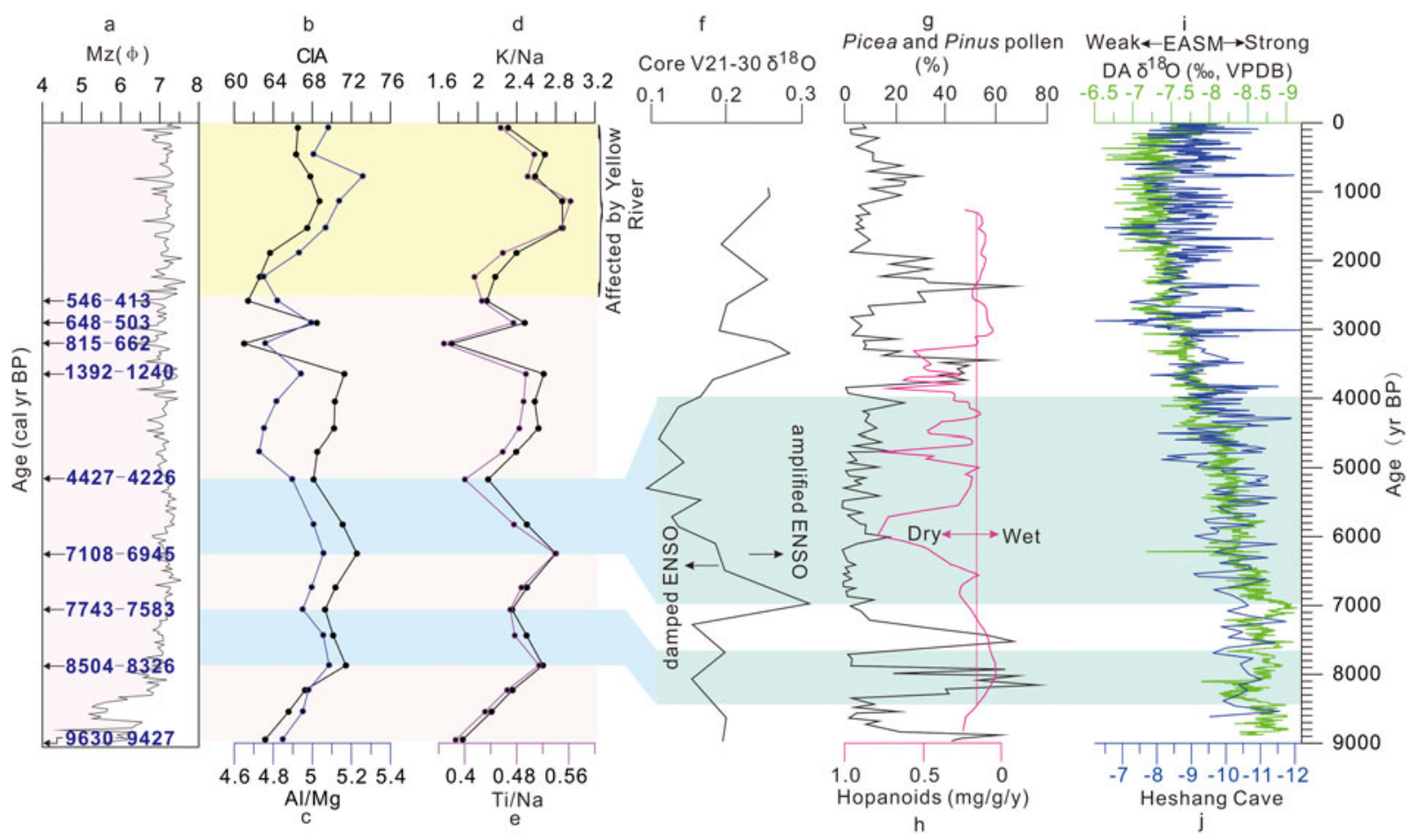

Figure 6. (color online) Climate conditions in Yangtze River basin since the early Holocene inferred from mean grain size (Mz) (a), chemical weathering index $\mathrm{CIA}$ (b), $\mathrm{Al} / \mathrm{Mg}(\mathrm{c}), \mathrm{K} / \mathrm{Na}(\mathrm{d})$, and Ti/Na (e) in core ECS0702; observed ENSO variability from foraminiferal $\delta^{18} \mathrm{O}(\mathrm{Koutavas}$ and Joanides, 2012) (f); Picea and Pinus pollen record at Lake Zhuyeze in arid China (Chen et al., 2006) (g); hopanoid accumulation rate in Dajiuhu peatland, for which high (low) accumulation rates correlate with dry (wet) intervals (Zhu et al., 2017) (h); and the summer monsoon proxy of stalagmite $\delta^{18} \mathrm{O}$ at Dongge Cave (Wang et al., 2005) (i) and Heshang Cave (Hu et al., 2008) (j).

has been proposed that evolution in the intensity of the EASM is closely linked to the strength of the ENSO (Li et al., 2011), especially the El Niño events (Jiang et al., 2006). Our record of weathering indexes appears to be consistent with paleoENSO proxies available for the Holocene (Fig. 6b-f). These results, together with our data, support an early Holocene optimum in China.

After the middle Holocene until 500 cal yr BP, our results show that the EASM intensity generally increased in the Yangtze River basin (Fig. 6b-e). This trend agrees well with the moisture changes indicated by the aerobic microbial biomarkers in the Dajiuhu peat and the environmental magnetism record from Heshang Cave during this interval (Xie et al., 2013). The carbon isotope composition of the soilderived acid-soluble organic matter in the HS4 stalagmite also detected a wet period during the late Holocene ( $\mathrm{Li}$ et al., 2014). In the China, chemical weathering intensity from Poyang Lake also showed an overall enhanced trend during the last $4000 \mathrm{yr}$, suggesting an ongoing humid climatic condition. Additionally, the increasing storm frequency inferred from the magnetic records in Heshang Cave provided additional support for the humid climatic conditions over the late Holocene (Zhu et al., 2017).

The $\delta^{18} \mathrm{O}$ record of Dongge Cave (Fig. 1a) showed some similarity of structure with Heshang Cave (Dykoski et al., 2005; Hu et al., 2008), indicating that it could also reflect the EASM variation in Yangtze River basin. High-resolution Dongge Cave $\delta^{18} \mathrm{O}$ data suggested that the EASM was punctuated by some weak EASM events during the Holocene, each lasting $\sim 1$ to 5 centuries. Among these cooling events, the $\sim 8.2 \mathrm{cal} \mathrm{ka} \mathrm{BP}(8.4$ to $8.1 \mathrm{cal} \mathrm{ka} \mathrm{BP})$ and $\sim 4.4$ cal ka BP (4.5 to $4.0 \mathrm{ka} \mathrm{BP}$ ) cooling events were longer in duration and larger in magnitude (Wang et al., 2005).

These two noticeable cooling events were also documented by core ECS0702. Our study displays that the EASM intensity is weak during the period of 8504-8326 to $7743-7583$ cal yr BP. The weathering indexes begin to decrease at 8504-8326 cal yr BP (Fig. 6b-e), coinciding with the beginning of the $\sim 8.2$ cal ka BP cooling event (Neff et al., 2001; Gupta et al., 2003). However, the decreasing trend of weathering indexes did not stop until 7743-7583 cal yr BP (Fig. 6b-e). The end of this cold period was consistent with the $\sim 7.7 \mathrm{cal} \mathrm{ka} \mathrm{BP}$ cooling event $(7780-7600 \mathrm{cal} \mathrm{yr}$ $\mathrm{BP}$ ) recorded in a sediment core from the upper region of the Yangtze River delta plain (Song et al., 2017). In other words, the weak EASM period (8504-8326 to 7743-7583 cal yr BP) in this study not only documents the $\sim 8.2$ cal ka BP cooling event but also the $\sim 7.7 \mathrm{cal}$ ka BP cooling event. The distinction between these two cooling events has not been recognized in ECS0702 due to low sample resolution. Another major $\sim 4.4$ cal ka BP cooling event ending at 4427-4226 cal yr BP in this study also coincides with previous reports (Wang et al., 2005; Hong et al., 2003; Fig. 6b-e). In addition to the above two cooling events, other weak EASM events centered at $\sim 5.5$ and $\sim 6.3 \mathrm{cal}$ ka BP also showed sedimentary imprinting in our studied core ECS0702 (Fig. 6b-e). Core 
ECS0702 also records a $\sim 0.7$ yr BP cooling event (Fig. 6be), which was also found in the $\delta^{18} \mathrm{O}$ record of Dongge Cave (Wang et al., 2005).

\section{Sedimentary record of flood caused by EASM}

Grain-size analysis is widely used to reconstruct depositional environments (Owen, 2005) and reveal ancient flood events (Brown et al., 2000; Nan et al., 2014). In river-mouth deposits, an abrupt increase of coarser-grained sediment with little or no fine-grained sediment is usually associated with conditions of high river discharge associated with floods (Holz et al., 2007; Dinakaran and Krishnayya, 2011). In general, high precipitation rates enhance soil erosion over the river basin (Zong et al., 2010) and increase the transport capacity of rivers, leading to coarser-grained sediment being available for river transport (Nan et al., 2014). Several studies have showed that sediment grain size and sorting coefficient increase during strong monsoon rainfalls (Zhan et al., 2010). Peak values of coarser sensitive grain-size populations and sorting coefficient were recorded at 543-413, 15671403, 2404-2217, 2552-2334, 3900-3694, 5354-5162, and 7622-7465 cal yr BP in core ECS0702 (Fig. 7). The size-frequency curves (Fig. 5a-g) and cumulative probability curves (Fig. 5a-g) of those samples mainly formed in nearshore shallow-sea environments (Liu et al., 2010) show similar characteristics to estuarine-inner shelf sediments produced by Yangtze River floods (Zhao et al., 2016). The sample collected at a depth of $16.05 \mathrm{~m}$ also mainly formed in a nearshore shallow-sea environment (Liu et al., 2010); however, its size- frequency and cumulative probability curves are different from the adjacent samples, as it was mainly deposited from suspension corresponding to the sedimentary characteristics of a low-energy subaqueous delta-front environment. The size-frequency and cumulative probability curves of the sample collected at a depth of $24.35 \mathrm{~m}$ show evidence of strong hydrodynamic conditions corresponding to the sample being deposited in a nearshore, subtidal environment (Liu et al., 2010). Therefore, the grain-size characteristics of sediments deposited at 543-413, 1567-1403, 2404-2217, 2552-2334, 3900-3694, 5354-5162, and 7622-7465 cal yr BP were mainly caused by Yangtze River floods.

The geophysical parameter IRM soft-flux $_{\text {represents the flux }}$ of soil-derived magnetic minerals preserved in stalagmite Heshang4 from Zhu et al. (2017), which correlates with rainfall amount and intensity (Fig. 7f). As shown in Figure 7, it is notable that the flooding events recorded in core ECS0702 correspond with the strong rainfall events. Previous studies have suggested that the EASM was strongly influenced by ENSO during the Holocene (Marchitto et al., 2010; Zhu et al., 2017). The strong ENSO activity during the early and late Holocene is roughly consistent with the humid period indicated by the chemical weathering proxies from core ECS0702 (Fig. 6b-f). This suggests that a stronger ENSO can trigger plentiful precipitation in the Yangtze River basin. During the middle Holocene, the ENSO intensity was significantly reduced (Cobb et al., 2013; Carré et al., 2014), resulting in fewer El Niño-related flood events in the Yangtze River basin (Fig. 7b-f). Increased frequency of ENSO-related storms during the late Holocene caused a corresponding increase of

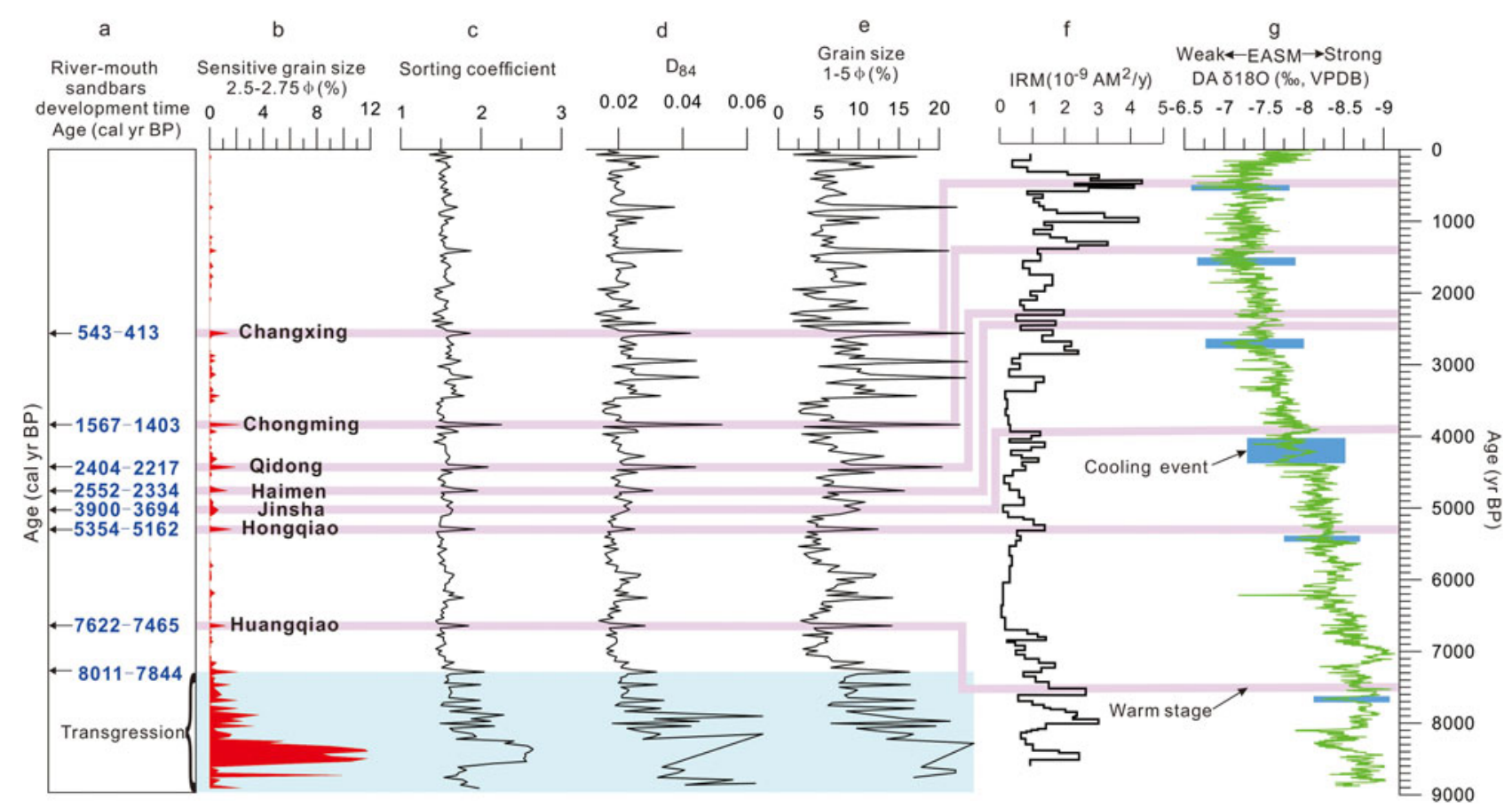

Figure 7. (color online) The Yangtze River mouth sandbar development time since the early Holocene (a), the vertical trends of sensitive grain

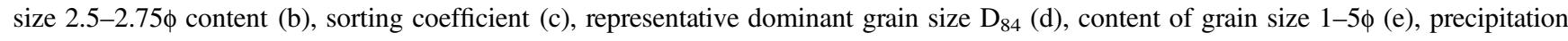

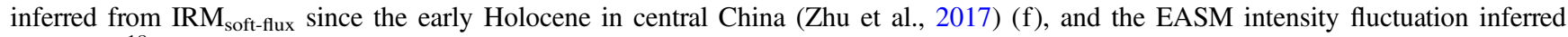
from the $\delta^{18} \mathrm{O}$ record of Dongge Cave (Wang et al., 2005) (g). 
flooding events in the Yangtze River Basin (Fig. 7b-f). Based on our data and data from the literature, generally, it was found that seven flooding periods caused by strong EASM were documented in core ECS0702.

\section{Development of the river-mouth sandbar}

River-mouth sandbars are fundamental morphological units of a delta, and their formation is typically controlled by the balance between upstream fluvial energy and downstream marine energy (Galloway, 1975). According to Edmonds and Slingerland (2007), river-mouth sandbar formation is due to the reduction of the sediment transport capacity and the decrease in the jet momentum flux when the flow expands into a standing body of water. More specifically, the decrease in the jet momentum flux is responsible for the formation of river-mouth sandbars (Edmonds and Slingerland, 2007). Recent progress has been made through the use of physical (Hoyal and Sheets, 2009; Martin et al., 2009) and numerical (Edmonds and Slingerland, 2010; Geleynse et al., 2011) experiments of delta formation, suggesting that grain size exerts a significant control on deltaic processes (Orton and Reading, 1993). A report from Caldwell and Edmonds (2014) showed that grain-size effect on deltaic processes is evident in the presence of both waves and tides, indicating that sediment properties may exert a stronger control than previously thought and the effect of sediment properties on deltaic processes may be a first-order control. A delta with a representative dominant grain size $\mathrm{D}_{84}=0.04-0.4 \mathrm{~mm}$ is mainly dominated by the process of river-mouth sandbar construction (Caldwell and Edmonds, 2014).

As discussed in the previous section, the floods were characterized by more coarse-grained sediments and a larger representative dominant grain size $\mathrm{D}_{84}$. During flood periods, the increased river discharge led to coarse-grained materials being available for river transport and subsequent deposition in the river mouth (Nan et al., 2014). The Yangtze River mouth is characterized by a trumpet shape, and this shape could decrease the river jet momentum flux. Therefore, at the Yangtze River estuary, the coarse-grained materials carried by the flood have a fast enough settling velocity to encourage sediment deposition near the channel mouth (Caldwell and Edmonds, 2014). In addition, during flood periods, although the Yangtze River mouth is dominated by the fluvial condition, tides enhance jet spreading, which in turn promotes lateral residual currents that facilitate the formation of bifurcating channels (Leonardi et al., 2013). This factor finally caused river-mouth sandbars to occur at the Yangtze River mouth. Therefore, the floods that occurred at 543-413, 1567-1403, 2404-2217, 2552-2334, 3900-3694, $5354-5162$, and $7622-7465$ cal yr BP easily formed rivermouth sandbars corresponding to development of the Hongqiao, Huangqiao, Jinsha, Haimen, Qidong, Chongming, and Changxing sandbars, respectively, as shown in Figure 7.

It is interesting that the sensitive grain-size populations $2.5-2.75 \phi$, as well as representative dominant $\mathrm{D}_{84}$ grain sizes, gradually increase from the Hongqiao to Chongming stages and then gradually decrease from the Chongming to Changxing stages. This phenomenon corresponds to the trend of the Yangtze River mouth gradually migrating from north to south since the early Holocene (Fig. 1b). Except during the Chongming stage, the location of core ECS0702 was far from the Yangtze River mouth, and the gravity differentiation sedimentation of sand carried by the floods caused few coarser grains to be transported to the location of core ECS0702. During the Chongming stage, the ECS0702 was located in the main channel of the Yangtze River to the sea, so each indicator presents its maximum value in the Chongming stage (Figs. $1 \mathrm{~b}$ and $7 \mathrm{~b}-\mathrm{e}$ ).

Our results show that the Haimen sandbar and Hongqiao sandbar initiated at 2552-2334 cal yr BP and 7622-7465 cal yr BP, respectively, which is comparable with previous results (Li et al., 1979). Core Xj03, located on the Hongqiao sandbar, showed that there was an abrupt change in the claysized component at $\sim 7500$ cal yr BP (Song et al., 2013; Fig. 8a), which confirms our hypothesis is reasonable. As discussed earlier, the EASM was much weaker due to reduction in ENSO intensity during the middle Holocene. In addition, the precipitation inferred from IRM soft-flux $_{\text {during the middle }}$ Holocene in central China was also much lower (Zhu et al., 2017; Fig. 7h). Specially, the $\sim 4.5$ cal ka BP cooling recorded in ECS0702 is the start of the $\sim 4.4$ cal ka BP extreme cooling event (Wang et al., 2005). There were no conditions for forming river-mouth sandbars in the middle Holocene, especially at $\sim 4500{ }^{14} \mathrm{C}$ yr BP. It should be pointed out that at 5354-5162 cal yr BP, there was a flood period that could be verified by a strong rainfall inferred

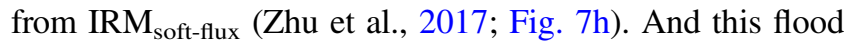
period caused the start of development of the Hungqiao sandbar, which could be also verified by the vertical variation of sediment grain size in core HQ98 (Hori et al., 2001; Yi et al., 2003; Fig. 8b).

The strong ENSO activity during the late Holocene could have triggered plentiful precipitation in the Yangtze River basin (Marchitto et al., 2010; Zhu et al., 2017) and caused floods to frequently occur (Fig. 7f). Therefore, many rivermouth sandbars started to develop from the middle Holocene, such as the Jinsha sandbar (3900-3694 cal yr BP), the Haimen sandbar (2552-2334 cal yr BP), the Qidong sandbar (2404-2217 cal yr BP), the Chongming Sandbar (15671403 cal yr BP), and the Changxing sandbar (543-413 cal yr BP). The start of development of the Jinsha, Qidong, and Chongming sandbars can also be verified by cores JS98 (Hori et al., 2001; Yi et al., 2003; Fig. 8c), QD (Liu et al., 1992; Zhao et al., 2018; Fig. 8d) and CM97 (Hori et al., 2001; Yi et al., 2003; Zhao et al., 2018; Fig. 8e), respectively. In summary, our results suggest that the Yangtze River-mouth sandbars mainly started to develop during stronger EASM periods with warm and humid environments.

It was previously suggested that the Yangtze River-mouth sandbar shifting from north to south during the Holocene was mainly caused by the action of tidal currents and the Coriolis force (Delta Research Group, Department of Marine Geology, Tongji University, 1978; Li et al., 1979; Fig. 1b). However, 

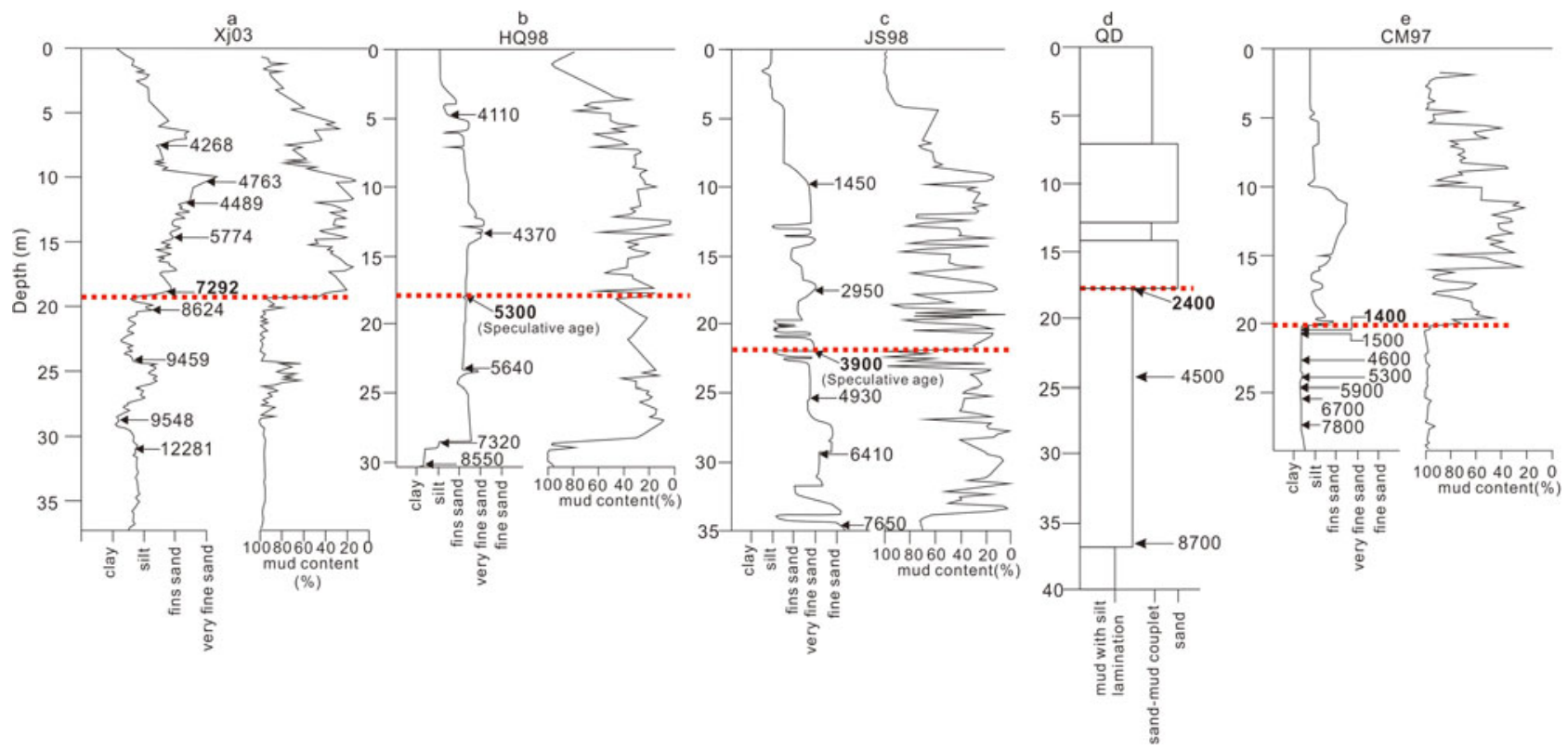

Figure 8. (color online) The vertical characteristics of lithology and mud content as well as the chronological framework of cores Xj03 (modified after Song et al., 2013) (a), HQ98 (modified after Hori et al., 2001; Yi et al., 2003; Feng et al., 2016) (b), JS98 (c) (modified after Hori et al., 2001; Yi et al., 2003; Feng et al., 2016), QD (modified after Liu et al., 1992; Zhao et al., 2018) (d), and CM97 (modified after Hori et al., 2001; Yi et al., 2003; Zhao et al., 2018) (e).

we believe that this phenomenon, while being affected by tidal currents and the Coriolis force, is more importantly influenced by the EASM. The discussion presented here has made clear that the floods have caused the river-mouth sandbars to develop during the stronger EASM periods. After the flood periods, the river discharge decreased and its estuary was mainly dominated by tidal currents. At low tide, even an incipient river-mouth bar became an obstacle to the flow. As a result, more materials were deposited on the river-mouth sandbar, speeding up its initial development. Once the two bifurcating channels were emplaced, strong ebb flows became established at low tide. These fast, shallow flows transported large quantities of sediments around the sandbar (Leonardi et al., 2013). During the weaker EASM period, the water depth over the sandbar was shallow enough to create an upstream fluid pressure that was capable of forcing the water around the sandbar rather than over the sandbar (Edmonds and Slingerland, 2007; Zhu et al., 2017). Therefore, the earlier-formed sandbar stopped aggradation and emerged from the water in this period. In addition, the Coriolis force caused the early-formation sandbar to mainly prograde southward, which, combined with the decreased water discharge, finally led to the southward migration of the main channel of the Yangtze River. In the following flood period, another river-mouth sandbar started to develop in the newly migrated southern river channel. Based on this evolution model, the Yangtze River-mouth sandbars shifted from north to south as they formed.

\section{CONCLUSIONS}

Based on multiproxy criteria, a relative high-resolution EASM record since the early Holocene was established for the Yangtze River basin: an early Holocene optimum $\operatorname{EASM}(\sim 9.5$ to $\sim 7.0 \mathrm{cal} \mathrm{ka} \mathrm{BP})$, a weak EASM in the middle Holocene ( $\sim 7.0$ to $\sim 4.0$ cal ka BP), and a generally strong EASM in the late Holocene (since $\sim 4.0$ cal ka BP). Our borehole provides a good record of the $\sim 8.2$ and $\sim 4.4$ cal ka BP cold events with longer durations and larger magnitudes, as well as other cold events. The grain-size parameters suggest that flooding events in the Yangtze River basin were mainly caused by a stronger EASM. The representative dominant grain size $\mathrm{D}_{84}$, sensitive grain-size populations, and sorting coefficients, indicate that the development of Yangtze River-mouth sandbars since the early Holocene were mainly controlled by the floods. Floods that occurred at 543-413, 1567-1403, 2404-2217, 2552-2334, 3900-3694, 53545162 , and 7622-7465 cal yr BP correspond to development of the Hongqiao, Huangqiao, Jinsha, Haimen, Qidong, Chongming, and Changxing sandbars, respectively. While the Yangtze River mouth sandbars since the early Holocene shifted from north to south, affected by tidal currents and the Coriolis force, they were more importantly controlled by the EASM.

\section{ACKNOWLEDGMENTS}

We sincerely appreciate the constructive comments from the editor Derek Booth, Aleeya Rahman, the reviewer Brian G. Jones, and one anonymous reviewer for improving the final article. Financial support for this study was primarily provided by the National Natural Science Foundation of China (grant nos. 41330964, 41406078, and 41676052) and the Marine Safeguard Project (grant no. GZH201200506). In addition, this study was also funded by the Taishan Scholars Program of Shandong Province, China (grant no. ts201511077). 


\section{REFERENCES}

An, Z.S., Porter, S.C., Kutzbach, J.E., Wu, X.H., Wang, S.M., Liu, X.D., Li, X.Q., Zhou, W.J., 2000. Asynchronous Holocene optimum of the East Asian monsoon. Quaternary Science Reviews 19, 743-762.

Bond, G., Showers, W., Cheseby, M., Lotti, R., Almasi, P., deMenocal, P., Priore, P., Cullen, H., Hajdas, I., Bonani, G., 1997. A pervasive millennial-scale cycle in North Atlantic Holocene and glacial climates. Science 278, 1257-1266.

Brown, S.L., Bierman, P.R., Andrea, L., 2000. $10000 \mathrm{yr}$ record of extreme hydrologic events. Geology 28, 335-338.

Caldwell, R.L., Edmonds, D.A., 2014. The effects of sediment properties on deltaic processes and morphologies: a numerical modeling study. Journal of Geophysical Research Earth Surface 119, 961-982.

Carré, M., Sachs, J. P., Purca, S., Schauer, A. J., Braconnot, P., Falcón, R.A., Julien, M., Lavallée, D., 2014. Holocene history of ENSO variance and asymmetry in the eastern tropical Pacific. Science 345, 1045-1048.

Chen, C.T.A., Lan, H.C., Lou, J.Y. and Chen, Y.C., 2003. The dry Holocene Megathermal in Inner Mongolia. Palaeogeography Palaeoclimatology Palaeoecology 193, 181-200.

Chen, F.H., Cheng, B., Zhao, Y., Zhu, Y., Madsen, D.B., 2006. Holocene environmental change inferred from a high-resolution pollen record, Lake Zhuyeze, arid China. Holocene 16, 675-684.

Chen, J., Zhu, H., Dong, Y., Sun, J., 1985. Development of the Changjiang estuary and its submerged delta. Continental Shelf Research 4, 47-56.

Chen, Z., Stanley, D., 1993a. Yangtze delta, eastern China: 1. Geometry and subsidence of Holocene depocenter. Marine Geology 112, 1-11.

Chen, Z., Stanley, D., 1993b. Yangtze delta, eastern China: 2. Late Quaternary subsidence and deformation. Marine Geology 112, 13-21.

Cobb, K.M., Westphal, N., Sayani, H.R., Watson, J.T., Di, L.E., Cheng, H., Edwards, R.L., Charles, C.D., 2013. Highly variable El Niño-Southern Oscillation throughout the Holocene. Science 339, 67-70.

Delta Research Group, Department of Marine Geology, Tongji University, 1978. Holocene formation and development of the Yangtze Delta. [In Chinese.] Chinese Science Bulletin 35, 310-313.

deMenocal, P.B., Ortiz, J., Guilderson, T., Sarnthein, M., 2000. Coherent high- and low-latitude climate variability during the Holocene warm period. Science 288, 2198-2202.

Dinakaran, J., Krishnayya, N.S.R., 2011. Variations in total organic carbon and grain size distribution in ephemeral river sediments in western India. International Journal of Sediment Research 26, 239-246.

Dykoski, C.A., Edwards, R.L., Cheng, H., Yuan, D.X., Cai, Y.J., Zhang, M.L., Lin, Y.S., Qing, J.M., An, Z.S., Revenaugh, J., 2005. A high-resolution, absolute-dated Holocene and deglacial Asian monsoon record from Dongge Cave, China. Earth and Planetary Science Letters 233, 71-86.

Edmonds, D.A., Slingerland R. L., 2007. Mechanics of river mouth bar formation: Implications for the morphodynamics of delta distributary networks. Journal of Geophysical Research Earth Surface 112, F02034.

Edmonds, D.A., Slingerland, R.L., 2010. Significant effect of sediment cohesion on delta morphology. Nature Geoscience 3, 105-109.
Feng, Z., Liu, B., Zhao, Y., Li, X., Jiang, L., Si, S., 2016. Spatial and temporal variations and controlling factors of sediment accumulation in the Yangtze River estuary and its adjacent sea area in the Holocene, especially in the Early Holocene. Continental Shelf Research 125, 1-17.

Folk, R.L.,Ward, W.C., 1957. Brazos River bar: a study in the significance of grain size parameters. Journal of Sedimentary Petrology 31, 514-519.

Gabet, E., Edelman, R., Langner, H., 2006. Hydrological controls on chemical weathering rates at the soil-bedrock interface. Geology 34, 1065-1068.

Galloway, W.E., 1975. Process Framework for Describing the Morphologic and Stratigraphic Evolution of Deltaic Depositional Systems. Houston Geological Society, Houston, TX.

Geleynse, N., Storms, J.E.A., Walstra, D.J.R., Jagers, H.R.A., Wang, Z.B., Stive, M.J.F., 2011. Controls on river delta formation; Insights from numerical modeling. Earth and Planetary Science Letters 302, 217-226.

Gupta, A.K., Anderson, D.M., Overpeck, J.T., 2003. Abrupt changes in the Asian southwest monsoon during the Holocene and their links to the North Atlantic Ocean. Nature 421, 354-357.

Holz, C., Stuut, J.-B.W., Henrich, R., Meggers, H., 2007. Variability in terrigenous sedimentation processes off northwest Africa and its relation to climate changes: inferences from grain-size distributions of a Holocene marine sediment record. Sedimentary Geology 202, 499-508.

Hong, Y.T., Hong, B., Lin, Q.H., Zhu, Y.X., Shibata, Y., Hirota, M., Uchida, M., Leng, X.T., Jiang, H.B., Xu, H., Wang, H., Yi, L., 2003. Correlation between Indian Ocean summer monsoon and north Atlantic climate during the Holocene. Earth and Planetary Science Letters 211, 371-380.

Hori, K., Saito, Y., Zhao, Q., Cheng, X., Wang, P., Sato, Y., Li, C., 2001. Sediment facies of the tide-dominated paleo-Changjiang (Yangtze) estuary during the last transgression. Marine Geology 177, 331-351.

Hori, K., Saito, Y., Zhao, Q.H., Wang, P.X., 2002. Architecture and evolution of the tide-dominated Changjiang (Yangtze) River delta, China. Sedimentary Geology 146, 249-264.

Hoyal, D.C.J.D., Sheets, B.A., 2009. Morphodynamic evolution of experimental cohesive deltas. Journal of Geophysical Research Earth Surface 114, F02009.

Hu, C., Henderson, G.M., Huang, J., Xie, S., Sun, Y., Johnson, K.R., 2008. Quantification of Holocene Asian monsoon rainfall from spatially separated cave records. Earth and Planetary Science Letters 266, 221-232.

Huang, C., Wei, G., Li, W., Liu, Y., 2018. A geochemical record of the link between chemical weathering and the East Asian summer monsoon during the late Holocene preserved in lacustrine sediments from Poyang Lake, central China. Journal of Asian Earth Sciences 154, 17-25.

Jiang, T., Zhang, Q., Zhu, D.M., Wu, Y.J., 2006. Yangtze floods and droughts (China) and teleconnections with ENSO activities (1470-2003). Quaternary International 144, 29-37.

Koutavas, A., Joanides S., 2012. El Niño-Southern Oscillation extrema in the Holocene and last glacial maximum. Paleoceanography $27, \mathrm{PA} 4208$.

Leonardi, N., Canestrelli, A., Sun, T., Fagherazzi, S., 2013. Effect of tides on mouth bar morphology and hydrodynamics. Journal of Geophysical Research: Oceans 118, 4169-4183.

Li, C., Chen, Q., Zhang, J., Yang, S., Fan, D., 2000a. Stratigraphy and paleoenvironmental changes in the Yangtze delta during Late Quaternary. Journal of Asian Earth Science 18, 63-79. 
Li, C., Wang, P., Fan, D., Dang, B., Li, T., 2000b. Open coast intertidal deposits and their preservation potential: a case study from east-central China. Sedimentology 47, 1039-1051.

Li, C., Wang, P., Sun, H., Zhang, J., Fan, D., Deng, B., 2002. Late Quaternary incised valley fill of the Yangtze delta (China): it stratigraphic framework and evolution. Sedimentary Geology $152,133-158$.

Li, C.X., Guo, X.M., Xu, S.Y., Wang, J.T., Li, P., 1979. The characteristics and distribution of Holocene sand bodies in Changjiang delta area. [In Chinese with English abstract.] Acta Oceanologica Sinica 1, 252-268.

Li, W., Zhai, P.M., Cai, J.H., 2011. Research on the Relationship of ENSO and the frequency of extreme precipitation events in China. Advances in Climate Change Research 2, 101-107.

Liu, K., Sun, S., Jiang, X., 1992. Environmental change in the Yangtze River delta since 12,000 years B.P. Quaternary Research 38, 32-45.

Liu, J., Saito, Y., Kong, X.H., Wang, H., Xiang, L.H., Wen, C., Nakashima, R., 2010. Sedimentary record of environmental evolution off the Yangtze River estuary, East China Sea, during the last $\sim 13,000$ years, with special reference to the influence of the Yellow River on the Yangtze River delta during the last 600 years. Quaternary Science Reviews 29, 2424-2438.

Liu, J.P., Xu, K.H., Li, A.C., Milliman, J.D., Velozzi, D.M., Xiao, S.B., Yang, Z.S., 2007. Flux and fate of Yangtze River sediment delivered to the East China Sea. Geomorphology 85, 208-224.

Liu, Z.Y., Lu, Z.Y., Wen, X.Y., Otto-Bliesner, B., Timmermann, A., Cobb, K.M., 2014. Evolution and forcing mechanisms of El Niño over the past 21,000 years. Nature 515, 550-553.

Marchitto, T.M., Muscheler, R., Ortiz, J.D., Carriquiry, J.D., van Geen, A., 2010. Dynamical response of the tropical Pacific Ocean to solar forcing during the early Holocene. Science 330, 1378-1381.

Martin, J., Sheets, B., Paola, C., Hoyal, D., 2009. Influence of steady base-level rise on channel mobility, shoreline migration, and scaling properties of a cohesive experimental delta. Journal of Geophysical Research Earth Surface 114, F03017.

McLennan, S.M., 1993. Weathering and global denudation. Journal of Geology 101, 295-303.

Milliman, J.D., Farnsworth, K.L., 2011. River discharge to the coastal ocean: a global synthesis. Cambridge University Press, Cambridge.

Milliman, J.D., Shen, H.T., Yang, Z.S., Mead, R.H., 1985.Transport and deposition of river sediment in the Changjiang estuary and adjacent continental shelf. Continental Shelf Research 4, 37-45.

Nan, Q., Li, T., Chen, J., Rajiv, N., Yu, X., Xu, Z., Yang, Z., 2014. Late Holocene ( 2 ka) East Asian monsoon variations inferred from river discharge and climate interrelationships in the Pearl River estuary. Quaternary Research 81, 240-250.

Nath, B.N., Kunzendorf, H., Plüger, W., 2000. Influence of provenance, weathering, and sedimentary processes on the elemental ratios of the fine-grained fraction of the bedload sediments from the Vembanad Lake and the adjoining continental shelf, southwest coast of India. Journal of Sedimentary Research 70, 1081-1094.

Nesbitt, H., Young, G., 1982. Early Proterozoic climates and plate motions inferred from major element chemistry of lutites. Nature 299, 715-717.

Nesbitt, H.W., Markovics, G., 1997. Weathering of granodioritic crust, long-term storage of elements in weathering profiles, and petrogenesis of siliciclastic sediments. Geochimica et Cosmochimica Acta 61, 1653-1670.
Neff, U., Burns, S.J., Mangini, A., Mudelsee, M., Fleitmann, D., Matter, A., 2001. Strong coherence between solar variability and the monsoon in Oman between 9 and 6 kyr ago. Nature 411, 290-293.

Nian, X.M., Zhang, W.G., Qiu, F.Y., Qin, J.T., Wang, Z.H., Sun, Q.L., Chen, J., Chen, Z.Y., Liu, N.K., 2019. Luminescence characteristics of quartz from Holocene delta deposits of the Yangtze River and their provenance implications. Quaternary Geochronology 49, 131-137.

Orton, G.J., Reading, H.G., 1993. Variability of deltaic processes in terms of sediment supply, with particular emphasis on grain size. Sedimentology 40, 475-512.

Porter, S.C., An, Z., 2005. Episodic gullying and paleomonsoon cycles on the Chinese Loess Plateau. Quaternary Research 64, 234-241.

Song, B., Li, Z., Lu, H.Y., Mao, L.M., Saito, Y., Yi, S., Lim, J., et al.., 2017. Pollen record of the centennial climate changes during 9-7 cal ka BP in the Changjiang (Yangtze) River Delta plain, China. Quaternary Research 87, 275-287.

Song, B., Li, Z., Saito, Y., Okuno, J., Li, Z., Lu, A.Q., Hua, D., Li, J., Li, Y.X., Nakashima, R., 2013. Initiation of the Changjiang (Yangtze) delta and its response to the mid-Holocene sea level change. Palaeogeography Palaeoclimatology Palaeoecology 388, 81-97.

Thompson, L.G., Thompson, M.E., Davis, M.E., Bolzan, J.F., Dai, J., Yao, T., Gundestrup, N., Wu, X., Klein, L., Xie, Z., 1989. Holocene-late Pleistocene climatic ice core records from the Qinghai-Tibetan Plateau. Science 246, 474-477.

Umbanhowar, C.E., Jr., Camill, P., Geiss, C.E., Teed, R., 2006. Asymmetric vegetation responses to mid-Holocene aridity at the prairie-forest ecotone in south-central Minnesota. Quaternary Research 66, 53-66.

Wang, B., Wu, R., Lau, K.M., 2001. Interannual variability of the Asian summer monsoon: contrasts between the Indian and the western North Pacific-East Asian monsoons. Journal of Climate 14, 4073-4090.

Wang, Y., Cheng, H., Edwards, R.L., He, Y., Kong, X., An, Z., Wu, J., Kelly, M.J., Dykoski, C.A., Li, X., 2005. The Holocene Asian monsoon: links to solar changes and North Atlantic climate. Science 308, 854-857.

Wang, Z.H., Saito, Y., Zhan, Q., Nian, X.M., Pan, D.D., Wang, L., Chen, T., Xie, J.L., Li, X., Jiang, X.Z., 2018. Three-dimensional evolution of the Yangtze River mouth, China during the Holocene: impacts of sea level, climate and human activity. EarthScience Reviews 185, 938-955.

Wei, G., Li, X., Liu, Y., Shao, L., Liang, X., 2006. Geochemical record of chemical weathering and monsoon climate change since the early Miocene in the South China Sea. Paleoceanography 21, PA4214.

West, A.J., Galy, A., Bickle, M., 2005. Tectonic and climatic controls on silicate weathering. Earth and Planetary Science Letters 235, 211-228.

Xie, S., Evershed, R.P., Huang, X., Zhu, Z., Pancost, R.D., Meyers, P.A., Gong, L., et al.., 2013. Concordant monsoon-driven postglacial hydrological changes in peat and stalagmite records and their impacts on prehistoric cultures in central China. Geology 41, 827-830.

Yang, X.P., 2000. Landscape evolution and precipitation changes in the Badain Jaran Desert during the last 30000 years. Chinese Science Bulletin 45, 1042-1047.

Yi, S., Saito, Y., Zhao, Q., Wang, P., 2003. Vegetation and climate changes in the Changjiang (Yangtze River) Delta, China, during 
the past 13,000 years inferred from pollen records. Quaternary Science Reviews 22, 1501-1519.

Zhan, W., Yang, S.Y., Liu, X.L., Li, J.W., Choi, M.S., 2010. Reconstruction of flood event over the last 150 years in the lower Changjiang reaches. Chinese Science Bulletin 55, 2268-2274.

Zhao, Y.F., Zou, X.Q., Gao, J.H., Wang, C.L., 2016. Recent sedimentary record of storms and floods within the estuarine-inner shelf region of the East China Sea. The Holocene 27, 439-449.

Zhao, B., Yan, X., Wang, Z., Shi, Y., Chen, Z., Xie, J., Chen, J., He, Z., Zhan, Q., Li, X., 2018. Sedimentary evolution of the Yangtze River mouth (East China Sea) over the past 19,000 years, with emphasis on the Holocene variations in coastal currents. Palaeogeography Palaeoclimatology Palaeoecology 490, 431-449.

Zheng, Y.H., Singarayer, J.S., Cheng, P., Yu, X.F., Liu, Z., Valdes, P.J., Pancost, R.D., 2014. Holocene variations in peatland methane cycling associated with the Asian summer monsoon system. Nature Communications 5, 4631.
Zhou, W., Yin, K., Harrison, P.J., Lee, J.H.W., 2012. The influence of late summer typhoons and high river discharge on water quality in Hong Kong waters. Estuarine, Coastal and Shelf Science 111, 35-47.

Zhou, W.J., Yu, X.F., Jull, A.J.T., Burr, G., Xiao, J.Y., Lu, X.F., Xian, F., 2004. High-resolution evidence from southern China of an early Holocene optimum and a mid-Holocene dry event during the past 18,000 years. Quaternary Research 62, 39-48.

Zhu, Z., Feinberg, J.M., Xie, S., Bourne, M.D., Huang, C., Hu, C., Cheng, H., 2017. Holocene ENSO-related cyclic storms recorded by magnetic minerals in speleothems of central China. Proceedings of the National Academy of Sciences USA 114, 852-857.

Zong, Y., Yu, F., Huang, G., Lloyd, J.M., Yim, W., 2010. Sedimentary evidence of Late Holocene human activity in the Pearl River delta, China. Earth Surface Processes and Landforms 35, 1095-1102. 